\title{
Application of Technology Acceptance Model (TAM) in predicting user intention to use Malaysian Business Reporting System (MBRS): A Conceptual Paper
}

\author{
Roslee Bin Uyob ${ }^{1}$ and Nor Syahridah Binti Noh ${ }^{2}$ \\ ${ }^{1}$ Department of Commerce, Politeknik Sultan Abdul Halim Muadzam Shah (POLIMAS), \\ Jitra Kedah, Malaysia. \\ ${ }^{2}$ Department of Commerce, Politeknik Sultan Abdul Halim Muadzam Shah (POLIMAS), \\ Jitra Kedah, Malaysia.
}

\begin{abstract}
On 27 September 2018, SSM has introduce a new submission platform known as Malaysian Business Reporting System (MBRS) that allow company in Malaysia to submit annual submission filing in Extensible Business Reporting Language (XBRL) format. Currently, submission filing using MBRS platform is only mandatory for unaudited companies' and Certificate for Exempt Private Company (EPC) but it is expected that the mandatory submission shall be enforced to other type of companies soon. By applying Theory Acceptance Model (TAM), this study proposes a conceptual model to examine the behavioral intention to use MBRS by accounting practitioners in Malaysia. The resulting model will guide the development of strategies, especially for the Companies Commission of Malaysia (SSM) in promoting MBRS adoption in the future reporting.
\end{abstract}

Key words: Malaysian Business Reporting System, MBRS, XBRL, Technology Acceptance Model, TAM, Behavioral intention, Perceived ease of use, Perceived usefulness, Attitude, Accounting practitioners, Malaysia

\subsection{INTRODUCTION}

Malaysian Business Reporting System (MBRS) is a new system that enables company in Malaysia to submit annual filings related to the financial statements such as financial statement reports (FS), annual return (AR) and exemption application (EA) in XBRL format [1]. It consists of three elements which is SSMxT, MTool (tool to convert excel file into XBRL format) and MPortal (online portal that enable submission filing via online). According to the SSM, the use of MBRS platform allows companies and regulators such as Inland Revenue Board of Malaysia (IRB) reduce time and costs in the process of gathering, sharing and exchanging financial and non-financial information amongst regulators, and reduce stored space for printed documents. [1]. For IRB It will give an opportunity to get quick, accurate and reliable information to assist them in achieving the objective of tax investigation and compliance [1][2][3]. Besides that, this platform is not only beneficial to the authorities in improving the public delivery system but also provides opportunities to reduce information asymmetries due to uniqueness of XBRL format characteristics [4][5] and also able to improve capital market information [5][6]. Therefore, it will helps accounting practitioners such as financial statement preparers, auditors, tax practitioners and financial advisory in giving and receiving reliable and valid information to improved their job [7][8][9][10].

However, since the introducing of SSMxT in 2014, the issue of XBRL format adoption by companies in Malaysia is still questionable. A study conducted by Azleen [11] found that no companies use XBRL format in their financial report and they are preferred to prepared report in traditional format such as pdf, excel or word due to low cost and less technical expert requirement [11]. Besides that, majority practitioners are worried about the operations cost incurred and also in doubt whether XBRL format could really improve the efficiency of their financial reporting process [12]. They also wondering whether MBRS is compatible with current scenario due to the complexity posed by XBRL [13]. Even though according to SSM, MBRS can give huge benefit and reduce time in submission process (via online and must submit in XBRL format) but the implementation of this new system maybe face a great challenge and will not succeed if the users feels 
that it was too complex and costly to them [11][12][13]. Indeed, on earlier adoption of XBRL system in U.S, the U.S. committee also expressed its concerns that requiring filers to adopt XBRL would resulted increase in costs but worried if no improvements to its internal processes [14]. Furthermore, prior studies has also found uncertainty on the reporting quality of XBRL, as errors or incompleteness of financial reporting are still happen [15][16][17][18].

In predicting the behavioral intention to adopt technology, TAM has been widely use in various discipline such as psychology, sociology and management due to its flexibility, robustness, and explanatory strength [19][20][21][22]. TAM has been introduced by Davis [23] on his doctoral thesis which based on concept from TRA [24]. TAM become so popular and has been cite in most of the research that deals with users' acceptance of technology [19][20][21][22][25]. By using TAM it help researchers and practitioners to determine why a particular technology or system may be acceptable or rejected and can take up suitable explanation measure besides providing prediction especially for new system implementation [25]. In TAM, user intention to use an application will explain and predict by his perception of the technology's usefulness and its simplicity [26].

Therefore, this paper proposes a model that adopts the Theory of Acceptance Model (TAM) to see factors influencing behavioral intention of accounting practitioners in Malaysia to use MBRS. Accounting practitioners are chosen as respondents in this study because they were the responsible person who directly involve in preparing, reviewing and submitting companies financial report in to the SSM on behalf of the companies. TAM theory suggests that attitudes, perceived usefulness, perceived ease of use [20][22][27][28][29] could explain the meaning of behavioral intention of accounting practitioners to use MBRS. The findings of this study may be useful for the Malaysian government (through SSM) to examine the factors influencing the behavioral intention toward MBRS and to find the best way to promote and encourage the use of MBRS among Malaysian businesses in the future. For the literature perspective, this study will also enhance the empirical understanding of TAM.

This paper is organized as follows. First, the prior literature of XBRL, MBRS and TAM theory is discussed. The second part, presents the research hypotheses and followed by a description of the methodology. Finally, is the conclusions of the study is presented.

\subsection{LITERATURE REVIEWS}

2.1 General overview of the financial reporting and the emergence of XBRL.

Financial reporting is the written report of the financial information, which communicating the financial position of the company through several medium to inform various users of financial reporting for their decision-making process [30]. Nowadays, in rapid changing technology and development era, most especially internet, the language and visualization of the financial reporting has transformed from paper-based report into more digital based report. By using internet as a platform, many companies have progressively converted their financial report into digital report to enhance the efficiency and timely transmission of the financial information between the preparer and the user of financial statement for better decision-making process [31].

Despite of increasing amount of access to financial information using the internet medium, financial information is might not easily been integrated into analysis software's and spreadsheet. This kind of information requires an expensive, tedious work to extract the financial data and can give an error cutting and pasting transaction due to different format. This issue will make users of financial report, such as government authorities facing difficulty to extract required data from financial report of the companies to perform a valid analysis for authority's related decision. However, extensible business reporting language (XBRL), often known as "barcodes for reporting" with its unique tagging features can solved this problem [32]. Many scholars of XBRL defined XBRL as a meta-language that based on XML, which communicate the business information in electronic communication [4][8][30][33][34]. The tagging unique structure in XBRL allowed inter-operability even though with different format which can improve the disclosure and analysis of management or corporate data [35]. This tool will act as a machine-readable format to provide consistent and accurate financial information and play a significant role in transferring the report data into different format. XBRL as an internet based language in web based reporting and disclosure technology, has enables the users of financial reporting including government, financial analyst, investors and others user of financial information to easily extract, use and analyse firms financial information in a minutes [33]. This role of XBRL not only will promote cost saving, but also will increase integrity, efficiency, accuracy and reliability of financial data for decision making [31]. 
Since 1999, the using of XBRL was being promoting and supporting by world leading accounting and financial reporting firms as an open standard language for the electronic communication. Now XBRL has been use in more than 30 countries around the world and approximately 18 in Europe and the numbers is keep growing from years to years
[30]. Countries such as China, German, United States and Japan has already required companies to submit filing in XBRL format. According to the XBRL International [32], in 2018 about 20 countries business registrars with total 8 million filers submit their file using XBRL format. Below is some of the conducted study on XBRL adoption.

Table 1: XBRL adoption study by different authors

\begin{tabular}{|l|l|}
\hline Authors & \multicolumn{1}{|c|}{ XBRL impact } \\
\hline Yang and Liu [10], & $\begin{array}{l}\text { Give consistent comparability improvement in the post mandate XBRL period due to its } \\
\text { consistency, accuracy and reliability of the information. Comparability is a key } \\
\text { qualitative characteristic of accounting information that facilitates the comparison of } \\
\text { financial statements. }\end{array}$ \\
\hline Chong et al. [4], & $\begin{array}{l}\text { Enhance information dissemination and mitigate the information asymmetry problem } \\
\text { between borrowers and lenders. XBRL adoption will reduce cost of bank loan and cost } \\
\text { of borrowers. They can enjoy more favorable price and non- price terms of bank loan } \\
\text { contracts. }\end{array}$ \\
\hline $\begin{array}{l}\text { Liu, Luo, and Wang } \\
\text { [36], }\end{array}$ & $\begin{array}{l}\text { Reduce information asymmetry and increase market liquidity among European non- } \\
\text { financial firms. Investors are more reliant on reporting using XBRL. }\end{array}$ \\
\hline $\begin{array}{l}\text { Heidari Gandoman } \\
\text { and Rostami [38], }\end{array}$ & $\begin{array}{l}\text { Improve quality of financial reporting, transparency, efficiency of accounting processes } \\
\text { and improve funding for corporation. }\end{array}$ \\
\hline Dong et al. [7], & $\begin{array}{l}\text { Reduces firms' stock return synchronicity and reduces price delay. XBRL make } \\
\text { financial data standardized, tagged, and machine-readable. }\end{array}$ \\
\hline Bai et al. [6], & Improves information environment in the Japanese market. \\
\hline $\begin{array}{l}\text { Roohani and Zheng } \\
\text { [17] }\end{array}$ & $\begin{array}{l}\text { In earlier filings term, the incomplete XBRL filings was highly found on extensions part } \\
\text { especially by bigger and more complex firms. They also found that firms that have done } \\
\text { many XBRL filings are less likely to have major errors. }\end{array}$ \\
\hline Bartley et al. [15], & $\begin{array}{l}\text { Found a reduction in errors over the time. It shows that using VFP in XBRL was } \\
\text { successful, }\end{array}$ \\
\hline $\begin{array}{l}\text { Debreceny et al. } \\
\text { [16] }\end{array}$ & $\begin{array}{l}\text { Found that in the first round of submission, one quarter of the filings had errors. The } \\
\text { main cause of errors was inappropriate treatment in the instance documents of } \\
\text { underlying debit/credit assumptions in the taxonomy. }\end{array}$ \\
\hline Zhu and Fu [18], & Found that XBRL data standard has low completeness and relevancy. \\
\hline
\end{tabular}

Based on above literature, it shows that even though they are study that found XBRL improve the accuracy and reliability of financial information quality, but prior study also found that they are still uncertainty on the quality of XBRL reporting, as errors or incompleteness are found happen especially in the earlier adoption stage.

\subsection{XBRL in Malaysia.}

Towards author knowledge, in Malaysia context there are less research conducted regarding XBRL in Malaysia. Even though XBRL has being introduce in the past 10 years by XBRL Consortium, but XBRL reporting format is not so popular in Malaysia [37]. They preferred to report in traditional reporting format such as pdf, excel or word in reporting their business report rather than use more modern and digitalize report such as HTML or XBRL reporting format [38].

Based on author search in Scopus and Google Scholar database, only seven article found which related to the XBRL in Malaysia for the past 10 years (Refer Table 2). It shows that they are fewer studies conducted in area of XBRL in Malaysia perspectives.

Table 2 Article XBRL in Malaysia

\begin{tabular}{|l|l|l|}
\hline Author(s) & \multicolumn{1}{|c|}{ Title } & \multicolumn{1}{|c|}{ Findings } \\
\hline Azleen Ilias [12], & $\begin{array}{l}\text { The Practitioner's Expectation of } \\
\text { Real-Time Reporting: Case of } \\
\text { the Extensible Business } \\
\text { Reporting Language (XBRL). }\end{array}$ & $\begin{array}{l}\text { Practitioners are doubt whether adopting XBRL in } \\
\text { Malaysia could improve the efficiency of the } \\
\text { financial reporting process, accessibility to } \\
\text { financial information and audit process. They also } \\
\text { ready to attend any type of training on XBRL }\end{array}$ \\
\hline
\end{tabular}


Roslee \& Norsyahridah / International Journal of Business and Management, 4(4) 2020, Pages: 21-30

\begin{tabular}{|c|c|c|}
\hline & & $\begin{array}{l}\text { adoption. Most of them believed that pressure } \\
\text { action from government authority would ensure } \\
\text { implementation of XBRL report in the future. }\end{array}$ \\
\hline $\begin{array}{l}\text { Azleen Ilias et al. } \\
\text { [37] }\end{array}$ & $\begin{array}{l}\text { XBRL Adoption in Malaysia: } \\
\text { Perception of the Accountants } \\
\text { and Auditors }\end{array}$ & $\begin{array}{l}\text { Accountants and auditors in Malaysia are } \\
\text { wondering the impact of XBRL adoption. They } \\
\text { also found that lack of accounting qualification and } \\
\text { lack of training would be the challenges for XBRL } \\
\text { adoption in Malaysia. }\end{array}$ \\
\hline Azleen Ilias [11], & $\begin{array}{l}\text { The Existence of the Extensible } \\
\text { Business Reporting Language } \\
\text { (XBRL) In Malaysia : From A } \\
\text { Stakeholders 'Perspective }\end{array}$ & $\begin{array}{l}\text { Only a few respondents were fully aware of } \\
\text { XBRL, while the majority of respondents were } \\
\text { unaware about XBRL. However, } 67.2 \% \text { of } \\
\text { respondents are likely to know more about XBRL } \\
\text { technology. }\end{array}$ \\
\hline A Ilias et al. [13], & $\begin{array}{l}\text { The expectation of perceived } \\
\text { benefit of extensible business } \\
\text { reporting language (XBRL): a } \\
\text { case in Malaysia }\end{array}$ & $\begin{array}{l}\text { Only a few future adopters understand the positive } \\
\text { impact of XBRL adoption. They also wondering } \\
\text { whether XBRL compatible with the current } \\
\text { systems due to the complexity posed by XBRL } \\
\text { adoption. }\end{array}$ \\
\hline $\begin{array}{l}\text { Azleen Ilias, } \\
\text { Zulkeflee, Razak, and } \\
\text { Rahman [39] }\end{array}$ & $\begin{array}{l}\text { The Familiarity and Preferences } \\
\text { for Reporting Format among } \\
\text { Stakeholders }\end{array}$ & $\begin{array}{l}\text { They preferred to use traditional reporting format } \\
\text { rather than more modern format. } 91.1 \% \text { preferred } \\
\text { to use Portable Document Format (PDF), only } \\
8.9 \% \text { preferred to use Hyper Text Markup } \\
\text { Language (HTML) format. About } 81.8 \% \text { of the } \\
\text { users were familiar with the Portable Document } \\
\text { Format (PDF), and only 49.1\% familiar with } \\
\text { Hyper Text Markup Language (HTML) format. }\end{array}$ \\
\hline $\begin{array}{l}\text { Azleen Ilias, } \\
\text { Zulkeflee, Razak, and } \\
\text { Rahman Abd [38] }\end{array}$ & $\begin{array}{l}\text { How potential adopters in } \\
\text { Malaysia perceive the relative } \\
\text { advantage of extensible business } \\
\text { reporting language (XBRL)? }\end{array}$ & $\begin{array}{l}\text { Mixed findings on the XBRL perception towards } \\
\text { relative advantage. They also found that every item } \\
\text { regarding relative advantage would affect the } \\
\text { intention of future use. }\end{array}$ \\
\hline $\begin{array}{l}\text { Mohamad, Building, } \\
\text { and Ismail [40] }\end{array}$ & $\begin{array}{l}\text { The Awareness of the Extensible } \\
\text { Business Reporting Language } \\
\text { (XBRL) In Malaysia }\end{array}$ & $\begin{array}{l}\text { Only a few respondents was fully aware of XBRL, } \\
\text { while the majority of respondents were unaware } \\
\text { about XBRL. }\end{array}$ \\
\hline
\end{tabular}

From the literature, it shows that the awareness regarding XBRL are still low in Malaysia. Practitioners in Malaysia also in doubt about the usefulness of the XBRL in Malaysia reporting landscape. Besides that, they also inquiry whether XBRL are compatible with current system and easy to use. However, they are ready to attend any type of training to improve their knowledge on XBRL.

\subsection{Malaysian Business Reporting System (MBRS).}

At present, towards author knowledge, there is no empirical study has been conduct on MBRS. MBRS has officially launched by Deputy Domestic Trade and Consumer Affairs Minister, Mr. Chong Chieng Jen on 27 September 2018. According to him, by beginning November 2018 it will be mandatory for unaudited financial statements and Certificate for Exempt Private Company (EPC) to submit their filings using MBRS. Meanwhile for other type of companies, the submission using MBRS are on voluntary basis but it will become mandatory soon [41]. He also stated that, to date 4,000 company secretaries have undergone the necessary training to enhance their understanding and efficiency in updating information and data exchange to ensure readiness of MBRS implementations[42].

MBRS is a new system consist of three components, which is SSM Taxonomy (SSMxT), MBRS preparation tool (Mtool) and MBRS Portal (Mportal) [41]. SSMxT is a dictionary of financial and nonfinancial reporting element in XBRL taxonomy, which embedded in Mtool. Mtool is a preparation tools based on Microsoft Excel that allow companies to prepare documents (via online or offline) and able to generated annual return, financial statement and exemption application in XBRL format. While for Mportal, is a submission platform to lodge financial statement, annual return and exemption application to SSM. They also can make inquiry, check status and make necessaries related payment system via online [1].

According to Datuk Zahrah Abd Wahab Fenner, the CEO of SSM, the project of MBRS submission platform would benefit for about 600,000 companies in Malaysia [42]. MBRS is expected to improve the public delivery system, reducing business costs for companies and expedites the updating of 
information, data exchange, enforcement, and information dissemination to stakeholders [1]. Previously, the companies have to come to SSM office to submit all documents. The documents then will be scan manually, and SSM workers will manually handle the data. By using MBRS, this redundancy clerical work and manually operations will be eliminating [41]. Datuk Zahrah Abd Wahab Fenner also stated that MBRS is also being develop and design with sourced and manage suitable infrastructure to ensured that the system is allow with high availability and disaster recovery [42]. This is to ensure that the companies did not worry about losing their data once it has been upload. The contract to develop MBRS has been given to OMESTI to ensure the successful of this implementation project [43]. Besides that, OMESTI group has also been trusted to provide training to all Malaysian companies especially prepares of the financial statement such as accountant on how to use MBRS. The 1 day's intensive training has been conducted to educate prepares regarding the MBRS component and how to prepare and filing using MBRS submission platform [43].

\subsection{Technology Acceptance Model (TAM).}

According to Shiau and Chau [44], the dominant factor to explain and predict the behavior of an individual is that they intend to behave. Many theories such as theory of reasoned action (TRA), theory of planned behavior (TPB) and technology acceptance model (TAM) stated that people would act when they were intending to do. In predicting the behavioral intention to adopt technology, TAM has been widely use in various discipline such as psychology, sociology and management due to its flexibility, robustness, and explanatory strength [19][20][21][22]. TAM has been introduced by Davis in 1989 on his doctoral thesis which based on concept from TRA [24]. In this concept it suggests that an individual's behavior is initiated by his or her behavioral intention [22]. Intention can be defined as cognitive representation of a person's readiness to perform a certain behavior, and it is the immediate antecedent of behavior. The stronger the intention to perform a certain behavior, the more likely the person is to perform that behavior [24][45].

TAM able to analyze factors affecting intention to adopt technology which beyond perceptions of convenience and usefulness [25]. In TAM, it provides a basis for explaining the impacts of external variables on adoption decisions, with its basic postulates resting firmly on economic, utilitarian and attitudinal grounds [26] ( . TAM become so popular and has been cite in most of the research that deals with users' acceptance of technology [19][20][21][22][25]. By using TAM it help researchers and practitioners to determine why a particular technology or system may be acceptable or rejected and can take up suitable explanation measure besides providing prediction especially for new system implementation [25] (Lai, 2017). In TAM, user intention to use an application will explain and predict by his perception of the technology's usefulness and its simplicity [26] (Awa et al., 2015).

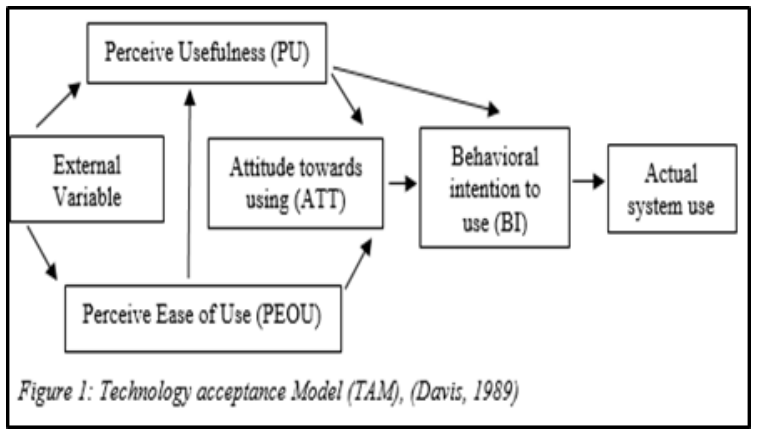

According to TAM theory, the use of technology depends on the intention (BI), and intention to use depends on the attitudes towards it's (AT) [20][22][27][28][29]. In TAM, this AT formed by an assessment of two variables, which is the perceived ease of use (PEOU) and the perceived usefulness (PU) towards the technology (figure 1) which being influence from external variable [20][22][27][28][29]. The base of these attitudinal models are more focusing on the benefits provided by technologies, and excluding the negative traits of its use [46]. TAM, describing the characteristics of the technologies processes will lead to the intentions of the user whether to accept or reject a technological innovation [46]. Therefore, based on the strength in TAM theory, TAM could explain the behavior intention of accounting practitioners in Malaysia to use MBRS in the future.

\subsection{RESEARCH HYPHOTHESIS}

Behavior intention will give a sign to the adoption of Malaysian companies to use MBRS in the future. Therefore, it will give a good opportunity to SSM to determine the proper taken action to ensure the success of MBRS project. To understand the relationship between factors influencing behavioral intention to use MBRS, the following hypotheses be used and tested. Thus, these hypotheses have been develop based on the proposed conceptual model and previous studies. 
Roslee \& Norsyahridah / International Journal of Business and Management, 4(4) 2020, Pages: 21-30

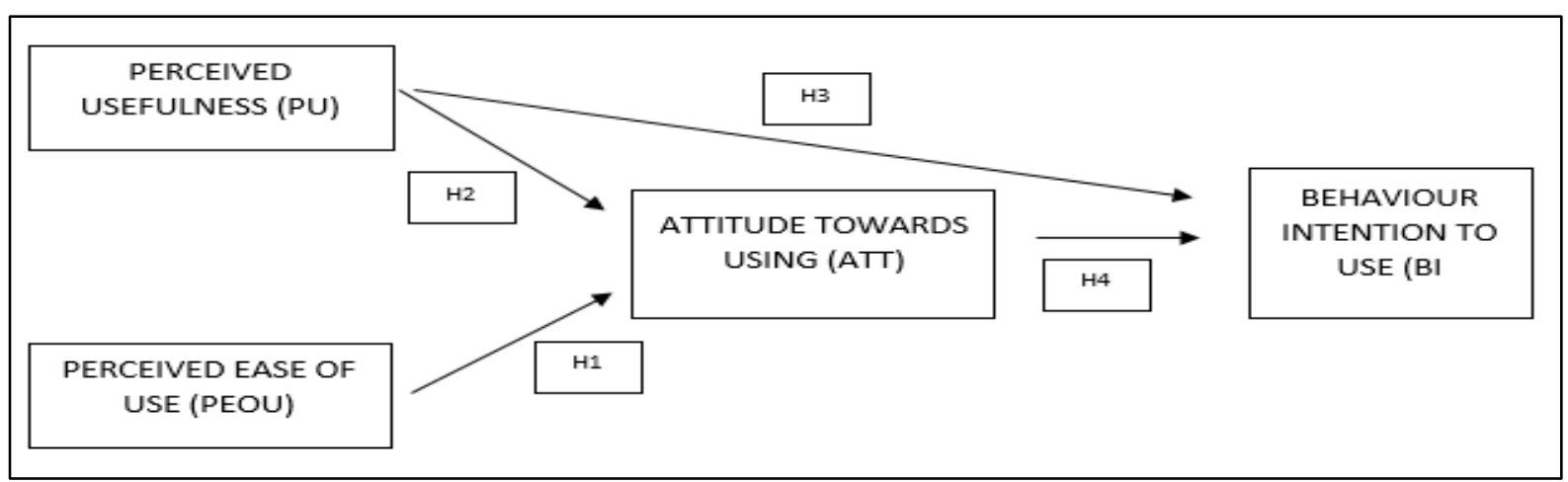

Figure 2: A proposed conceptual model

3.1 The relationship between perceived ease of use (PEOU) and attitude (AT) towards using MBRS.

The term perceived ease of use (PEOU) is the concept that represent an assessment of the degree to which interaction with a system or a specific information technology is free from mental effort [23][28]. For context of this study, PEOU is define as "the degree to which individuals feel free from engaging in mental and physical efforts in using MBRS."

In TAM both Perceived usefulness (PU) and perceived ease of use (PEOU) have been tested in many areas to describe or predict attitude and behavioral intention on different technologies such as e-banking, e-commerce, e-learning, e-library, etax filing, telemedicine technology, word processing, social networking media, smartcard and microcomputer [20][22][27][28][29]. An empirical research has found that both of this variable has a positive relationship towards attitude and behavior intention [20][22][27][28][29].

A research conducted by Yoon, [22] has found that PEOU had significant effects on user attitude (AT) towards new system application in library at Joongbu University. A research conducted by Muñoz-Leiva et al., [46] found that PEOU has a significant positive relationship with AT towards new mobile banking application system. Research by $\mathrm{Yu}, \mathrm{Yi}, \mathrm{Liu}$, and Feng, [47] also found that AT toward use of Commercial Bike-sharing Systems was positively affected by PEOU. Additionally, a study by Sarika, Preeti, Shilpy, and Sukanya, [48] found that PEOU of the system has a positive relationship towards AT to shop online. From above literature, it shows that, most of the study found positive relationship between PEOU and AT in technology adoption. The more PEOU towards system the more positive AT towards using the system. However a research conducted by Sabir, Ahmad, and Noor, [49] found that there were negative relationship between AT and PEOU in Social Networking Sites (Facebook) system among Pakistani university students. They found Pakistani students are not attracting towards enjoyment of using Facebook and the acceptance of technology is widely affected by their society social norm. From that, it shows mix findings regarding the relationship between PEOU and AT towards technology. Thus, hypothesis $\mathrm{H}_{1}$ was propose:

$\boldsymbol{H}_{1}$ : There is a positive and direct significant relationship between perceived ease of use (PEOU) and attitude towards using MBRS (AT).

3.2 The relationship between perceived usefulness (PU) and attitude towards using MBRS (AT).

Perceived usefulness (PU) can be define as the perception of individuals with regard to the improvement of the tasks performed when using the system in question [23][28]. In this study, PU defined as "perception of individual's practitioners with regard to the improvement of the tasks performed when using MBRS in question".

Many researchers have found positive relationship between PU and AT. A study conducted by Yu et al., [47] found that PU is significant towards AT to use commercial bike-sharing systems. A research conducted by Yoon, [22] has found that PU had significant effects on user attitude (AT) towards new system application in library at Joongbu University. A study conducted by Sarika et al., [48] also found that PU has significant impact on AT to shop online. Its shows that, the more PU towards system the more they would positive AT towards using the system. However, a study conducted by Sabir et al., [49] found that PU has not been verified to be a major element in examining BI to use Facebook among Pakistani university student. They found that the higher PU would not lead to positive AT towards using Facebook. PU will not change AT in using Facebook among Pakistani university student. Therefore, hypothesis $\mathrm{H}_{2}$ was propose:

$\mathrm{H}_{2}$ : There is significant positive relationship between perceived usefulness (PU) with attitude (AT) towards using MBRS. 
3.3 The relationship between perceived usefulness (PU) and behavioral intention (BI) to use MBRS.

A research conducted by Elkaseh et al., [27] ound that PU are important factors for predicting a student's and teachers' behavioural intention (BI) to use social networking media for e-learning in Libyan higher education. In this study, individual who feels that social media is more useful, will have more intention to use e-learning technology for learning in Libya [27]. A study conducted by Yu et al., [47] also shows that PU is a significant factor in predicting the BI to use commercial bike-sharing systems. Costs are among factor influencing in bikesharing systems adoption, and if users find the system is convenient and save time, they are more likely to adopt the system. A study conducted by Sarika et al., [48] also found that PU has significant impact on BI to shop online. However a study done by Muchran and Ahmar, [50] found that there is no significant relationship between PU with BI to use internet banking. They found that even though user has high experience in using the system, it does not moderate the perception of the benefits to the intention in using internet banking due to inconsistency of connection speed and security of internet banking system. Beside that a study to examine intention to use mobile banking apps conducted by Muñoz-Leiva et al., [46] also found that relationship between PU and BI is not confirmed and the relationship is very weak and without explanatory power. Thus, hypothesis $\mathrm{H}_{3}$ was propose:

$\boldsymbol{H}_{3}$ : There is significant positive relationship between perceived usefulness (PEOU) with behavior intention (BI) to use MBRS.

3.4 The relationship between attitude (AT) and behavioral intention (BI) to use MBRS.

Attitude (AT) is a motor concept or the physical expression of an emotion which refers to the degree of a person has a favorable and unfavorable evaluation or appraisal of the behavior in question [51]. According to the Fishbein and Ajzen, [24], AT also can be defined as the perceived degree of positive and negative feelings about doing the target behavior. In this study, AT can be define as "physical expression of an emotion which refers to perceived degree of positive and negative feelings about using MBRS".

Many empirical study has approved that AT has a positive relationship with the BI in different areas of technology usage [46][52][53][54]. The study on user acceptance towards library application conducted by Yoon [22] has founded that AT has a significant towards the BI of people in Joongbu
University to use library application. Besides that, a study conducted by Khoi et al. [53] also has found that Vietnamese consumers' AT has a positive relationship with BI to adopt mobile commerce. A study conducted by Sarika et al.[48] also found that AT has significant impact on BI to shop online. It shows that the more positive AT towards system the more likely BI to use the system. However a research conducted by Sabir, Ahmad, and Noor found no relationship between AT and BI of Social Networking Sites (Facebook) system among Pakistani University Students. They found that, social norm has strong effect on BI to use Facebook among Pakistani University Students rather than AT. Thus, the following hypotheses $\mathrm{H}_{4}$ were develop.

$\boldsymbol{H}_{4}$ : There is significant positive relationship between attitudes (AT) with behavior intention (BI) to use MBRS.

\subsection{METHODOLOGY}

In Malaysia, submission filings to SSM are mandatory required every year. Penalties will be given to the companies who fail to submit their filing according to the prescribe time. This study choose accounting practitioners as a population of this study since accounting practitioners are the person who responsible to prepared, handle and submit all the submission filing requirement [55]. The data was propose to obtain from accounting practitioners who practices in big city and located in peninsular Malaysia since in this area involve with many business activities and many big companies operates in this area.

A structured questionnaire will be use as a method of sampling. Based on statistic on 2014 by Accountant General's Department of Malaysia, the number of sample will be identify and questionnaires will be distribute accordingly to respondents on random basis from the address list obtained from Malaysia Institute of Accountant directory.

To analyze the data, one statistical technique will be use. Habidin and Yusof [58] mentioned that structural equation modeling (SEM) is a method of data analysis that being increasingly used in empirical studies. SEM using AMOS 6.0 used to test the measurement model and SEM techniques were utilize to perform the required statistical analysis of the data from the survey. Exploratory factor analysis, reliability analysis and confirmatory factor analysis will use to test for construct validity, reliability and the measurements loading will be perform. The statistical Package for the Social Sciences (SPSS) version 23 will be use to analyze the preliminary data and provide descriptive 
analyses about thesis sample such as means, standard deviations and frequencies.

\subsection{CONCLUSIONS}

MBRS is the new system launched by Malaysian government through SSM that incurred a lot amount of investment. The success or failure of this project is depends on the amount of the user who use this system in the future. This research attempts to provide an insight into its facets, thus, providing useful input on the intention to use MBRS.

Many researchers has consider TAM as the most influential theoretical approach in the context of study related to the technology due to its flexibility, robustness, and explanatory strength [56][57]. Therefore, this study proposes to empirically test whether TAM theory construct also can explain factors that influence behavioral intention to use MBRS.

Based on proposed model and previous study, research hypotheses were developed. A conceptual model has been proposed to examine behavioral intention to adopt Malaysian Business Reporting System (MBRS) among Malaysian companies. The next step of this study is to design a questionnaire, which will use for pilot study and data collection. This study is expected to provide a valid and reliable for instrument and structural relationship model for behavioral intention to adopt Malaysian Business Reporting System (MBRS).

\section{REFERENCES}

[1] Suruhanjaya Syarikat Malaysia (SSM). (n.d.-a). Malaysian Business Reporting System (MBRS) frequently asked questions.

[2] Ahmad, F. (2015). Introduction to Malaysian Business Reporting System (MBRS).

[3] Norazimah. (2013). The Companies Commission of Malaysia' $S$ Xbrl Taxonomy for Financial Reporting Overview of SSM' $s$ XBRL Project.

[4] Chong, D., Shi, H., Fu, L., Ji, H., \& Yan, G. (2017). The impact of XBRL on information asymmetry: evidence from loan contracting. Journal of Management Analytics, 4(2), 145158.

[5] Liu, C., Yao, L. J., Sia, C. L., \& Wei, K. K. (2014). The impact of early XBRL adoption on analysts' forecast accuracy - Empirical evidence from China. Electronic Markets, 24(1), 47-55.

[6] Bai, Z., Sakaue, M., \& Takeda, F. (2014). The Impact of XBRL Adoption on theInformation Environment: Evidence from Japan. The Japanese Accounting Review, 4(2014), 49-74.
[7] Dong, Y., Li, O. Z., Lin, Y., \& Ni, C. (2016). Does Information-Processing Cost Affect Firm-Specific Information Acquisition? Evidence from XBRL Adoption. Journal of Financial and Quantitative Analysis, 51(2), 435-462.

[8] Heidari Gandoman, S., \& Rostami, M. (2017). Investigating the Effect of Extensible Business Reporting Language (XBRL) on Quality Improvement of Financial Reporting in Iranian Corporations. SSRN Electronic Journal, 1-14.

[9] Suruhanjaya Syarikat Malaysia (SSM). (n.d.-b). MBRS for preparers - financial statements introduction to MBRS.

[10] Yang, S., \& Liu, F. (2018). Network, Smart and Open. 24.

[11] Ilias, Azleen. (2015). The Existence of the Extensible Business Reporting Language (XBRL) In Malaysia: From A Stakeholders' Perspective. (FEBRUARY 2014), 1-49.

[12] Ilias, Azleen. (2017). The Practitioner's Expectation of Real-Time Reporting: Case of the eXtensible Business Reporting Language (XBRL). Global Business \& Management Research, 9(3), 1-15.

[13] Ilias, A, Razak, M., Areas, R. R.-T. J. of D., \& 2015, undefined. (n.d.). The expectation of perceived benefit of extensible business reporting language (XBRL): a case in Malaysia. Muse.Jhu. Edu.

[14] Dzinkowski. (2008). Do you speak XBRL? CA Magazine.

[15] Bartley, J., Chen, A. Y. S., \& Taylor, E. Z. (2011). A comparison of XBRL filings to corporate 10-Ks-evidence from the voluntary filing program. Accounting Horizons, 25(2), 227-245.

[16] Debreceny, R., Farewell, S., Piechocki, M., Felden, C., \& Gräning, A. (2010). Does it add up? Early evidence on the data quality of XBRL filings to the SEC. Journal of Accounting and Public Policy, 29(3), 296-306.

[17] Roohani, S. J., \& Zheng, X. (2013). Determinants of the Deficiency of XBRL Mandatory Filings. International Research Journal of Applied Finance Vol., 4(3), 502518.

[18] Zhu, H. (Harry), \& Fu, L. (2010). Quality of Data Standards: Empirical Findings from XBRL. Ssrn.

[19] Agrebi, S., \& Jallais, J. (2015a). Explain the intention to use smartphones for mobile shopping. Journal of Retailing and Consumer Services, 22, 16-23.

[20] Gangwar, H., Date, H., \& Ramaswamy, R. (2015). Understanding determinants of cloud computing adoption using an integrated TAMTOE model. Journal of Enterprise Information Management, 28(1), 107-130. 
[21] Shiau, W. L., \& Chau, P. Y. K. (2016b). Understanding behavioral intention to use a cloud computing classroom: A multiple model comparison approach. Information and Management, 53(3), 355-365.

[22] Yoon, H. Y. (2016). User Acceptance of Mobile Library Applications in Academic Libraries: An Application of the Technology Acceptance Model. Journal of Academic Librarianship, 42(6), 687-693. [23] Davis, F. D. (1989). Perceived Usefulness, Perceived Ease of Use, and User Acceptance of Information Technology. MIS Quarterly, 13(3), 319.

[23] Davis, F. D. (1989). Perceived Usefulness, Perceived Ease of Use, and User Acceptance of Information Technology. MIS Quarterly, 13(3), 319.

[24] Fishbein, M., \& Ajzen, I. (1975). Belief, Attitude, Intention and Behaviour: An Introduction to Theory and Research. Reading MA AddisonWesley, (May 1975), 480.

[25] Lai, P. C. (2017). The literature review of technology adoption models and theories for the novelty technology. 14(1), 21-38.

[26] Awa, H. O., Ojiabo, O. U., \& Emecheta, B. C. (2015). Integrating TAM, TPB and TOE frameworks and expanding their characteristic constructs for e-commerce adoption by SMEs. Journal of Science and Technology Policy Management, 6(1), 76-94.

[27] Elkaseh, A. M., Wong, K. W., \& Fung, C. C. (2016). Perceived Ease of Use and Perceived Usefulness of Social Media for e-Learning in Libyan Higher Education: A Structural Equation Modeling Analysis. (September 2015).

[28] Jahangir, N., \& Begum, N. (2008). The role of perceived usefulness, perceived ease of use, security and privacy, and customer attitude to engender customer adaptation in the context of electronic banking. 2(1), 32-40.

[29] Venkatesh, V., \& Davis, F. D. (2000). A Theoretical Extension of the Technology Acceptance Model: Four Longitudinal Field Studies. Management Science, 46(2), 186-204.

[30] Avallone, F., Ramassa, P., \& Roncagliolo, E. (2016). The Pros and Cons of XBRL Adoption in Italy: A Field Study. Springer International Publishing Switzerland 2016, 14(i), 157-170.

[31] Ib, C. E., Jide, I., \& Zik-Rullahi, A. A. (2015). The impact of XBRL on financial reporting: A conceptual analysis. International Journal of Empirical Finance, 4(2), 78-85.

[32] XBRL International. (n.d.). An Introduction to XBRL. Retrieved from https://www.xbrl.org/

[33] Choi, Y. M. (2016). The impact of XBRL adoption on corporate dividend policy: Evidence from Korean firms. Indian Journal of Science and Technology, 9(20).
[34] Liu, C., Wang, T., \& Yao, L. J. (2014). XBRL's impact on analyst forecast behavior: An empirical study. Journal of Accounting and Public Policy, 33(1), 69-82.

[35] Bonsón, E., Cortijo, V., \& Escobar, T. (2009). Towards the global adoption of XBRL using International Financial Reporting Standards (IFRS). International Journal of Accounting Information Systems, 10(1), 46-60.

[36] Liu, C., Luo, X. (Robert), \& Wang, F. L. (2017). An empirical investigation on the impact of XBRL adoption on information asymmetry: Evidence from Europe. Decision Support Systems, 93, 42-50.

[37] Ilias, Azleen, Ghani, E. K., \& Azhar, Z. (2017). XBRL Adoption in Malaysia: Perception of the Accountants and Auditors. (September).

[38] Ilias, Azleen, Zulkeflee, M., Razak, A., \& Rahman Abd, R. (2015). How potential adopters in Malaysia perceive the relative advantage of eXtensible business reporting language (XBRL)? Proceedings of the International Conference on Accounting Studies (ICAS) 2015, (August), 338-346.

[39] Ilias, Azleen, Zulkeflee, M., Razak, A., \& Rahman, R. A. (2015). The Familiarity and Preferences for Reporting Format among Stakeholders. An International Journal Research Paper Global Business \& Management Research an International Journal, 7(1), 1-20.

[40] Mohamad, R., Building, A., \& Ismail, N. A. (2010). The Awareness of the Extensible Business Reporting Language (XBRL) In Malaysia. Journal of Internet Banking and Commerce, 15(1), 1-11.

[41] Suruhanjaya Syarikat Malaysia (SSM). (2019). pengumuman berhubung pelaksanaan serah simpan penyata tahunan dan penyata kewangan melalui portal Malaysian Business Reporting System (MBRS). (September 2018), 7721.

[42] Radhi, N. A. M. (n.d.). Mandatory for companies to submit their documents to SSM via new platform soon. New Straits Times Press (M) Bhd.

[43] Services, F. N. (n.d.). MBRS Financial Statements MBRS for preparers: financial statements hands - on training for Mtool submission of financial statements \& key.

[44] Shiau, W. L., \& Chau, P. Y. K. (2016a). Understanding behavioral intention to use a cloud computing classroom: A multiple model comparison approach. Information and Management, 53(3), 355-365.

[45] Ajzen, I. (1991). The theory of planned behavior. Organizational Behavior and Human Decision Processes, 50(2), 179-211.

[46] Muñoz-Leiva, F., Climent-Climent, S., \& Liébana-Cabanillas, F. (2017). Determinantes 
de la intención de uso de las aplicaciones de banca para móviles: una extensión del modelo TAM clásico. Spanish Journal of Marketing ESIC, 21(1), 25-38.

[47] Yu, Y., Yi, W., Liu, J., \& Feng, Y. (2018). Understanding the Intention to Use Commercial Bike-sharing Systems: An Integration of TAM and TPB. 9, 646-655.

[48] Sarika, K., Preeti, S., Shilpy, S., \& Sukanya, S. (2015). A Study of Adoption Behavior for Online Shopping: An Extension of Tam Model.

[49] Sabir, R. I., Ahmad, W., \& Noor, N. (2013). Adoption of Social Networking Sites among Pakistani University Students: A Case of. 3(6), 125-139.

[50] Muchran, M., \& Ahmar, A. S. (2018). Application of TAM model to the use of information technology. 7, 37-40.

[51] Oly Ndubisi, N., \& Sinti, Q. (2006). Consumer attitudes, system's characteristics and internet banking adoption in Malaysia. Management Research News, 29(2000), 16-27.

[52] Ahmad, M. (2018). Review of The Technology Acceptance Model (TAM) in Internet banking and Mobile Banking Review of the Technology Acceptance Model (TAM) in Internet banking and Mobile banking. (November).
[53] Khoi, N. H., Tuu, H. H., \& Olsen, S. O. (2018). The role of perceived values in explaining Vietnamese consumers' attitude and intention to adopt mobile commerce. Asia Pacific Journal of Marketing and Logistics, 30(4), 1112-1134.

[54] Nabavi, A., Taghavi-Fard, M. T., Hanafizadeh, P., \& Taghva, M. R. (2016). Information Technology Continuance Intention. International Journal of E-Business Research, 12(1), 58-95.

[55] The Committee to Strengthen the Accountancy Profession. (2014). Report on the strengthening of the accountancy profession in malaysia. In Jabatan Akauntan Negara.

[56] Agrebi, S., \& Jallais, J. (2015b). Explain the intention to use smartphones for mobile shopping. Journal of Retailing and Consumer Services, 22, 16-23.

[57] Arning, K., \& Ziefle, M. (2007). Understanding age differences in PDA acceptance and performance. Computers in Human Behavior, 23(6), 2904-2927.

[58] Habidin, N. F. (n.d.). Critical success factors of Lean Six Sigma for the Malaysian automotive industry. 